\title{
SIMULASI KLASIFIKASI HAMA DAN PENYAKIT PADA JAGUNG DENGAN NAIVE BAYES
}

\author{
Muhammad Mushlih Suhadi ${ }^{1)}$, M. Alauddin Helmi' ${ }^{2)}$, Wahyudi Setiawan ${ }^{3)}$ \\ ${ }^{1,2,3}$ Prodi Teknik Informatika, Fakultas Teknik,Universitas Trunojoyo \\ Jl. Raya Telang, PO BOX 2 Kamal, Bangkalan \\ E-mail : ${ }^{3}$ wsetiawan@trunojoyo.ac.id
}

\begin{abstract}
ABSTRAK
Jagung merupakan komoditas pertanian terpenting setelah padi. Produktivitas jagung perlu senantiasa ditingkatkan dalam rangka swasembada jagung nasional. Jagung selain sebagai pangan juga digunakan untuk pakan (hewan), dan bahan baku industri. Salah satu hal yang dapat digunakan untuk memperbaiki produktivitas jagung yaitu dengan melakukan pencegahan terhadap serangan hama dan penyakit. Untuk itu perlu dibuat sistem untuk menyimpan pengetahuan tersebut. Pada artikel ini dibahas tentang klasifikasi hama dan penyakit pada tanaman jagung menggunakan Naive Bayes Classifier. Data yang digunakan berasal dari Dinas Pertanian Kabupaten Bangkalan. Data terdiri dari 15 hama dan penyakit serta 46 gejala. Ujicoba sistem dilakukan dengan simulasi melalui pengamatan terhadap 15 citra tanaman jagung. Hasil dari pengamatan secara langsung selanjutnya menjadi entri data untuk diolah menggunakan metode Naive Bayes. Untuk keperluan validasi hasil mining dari sistem dibandingkan dengan pendapat pakar. Uji validasi dari pakar menunjukkan prosentase kesesuaian hingga 73,33\%.
\end{abstract}

Kata kunci : Klasifikasi, Naive Bayes, Tanaman Jagung, Bangkalan, Hama dan Penyakit.

\begin{abstract}
Maize is the most important agricultural commodity after rice. Maize productivity needs to be continuously improved in the context of national maize self-sufficiency. Apart from being food, maize is also used for feed (animals), and industrial raw materials. One of the things that can be used to improve maize productivity is to prevent pests and diseases. For this reason, it is necessary to create a system to store this knowledge. This article discusses the classification of pests and diseases on maize using the Naive Bayes Classifier. The data used comes from the Department of Agriculture of Bangkalan. The data consisted of 15 pests and diseases and 46 symptoms. The system was tested by simulation of observing 15 maize plants images. The results of direct observations then become data entry to be processed using the Naive Bayes method. For the purposes of validating the mining results from the system, they are compared with expert opinions. Validation test from experts shows the percentage of conformity up to $73.33 \%$.
\end{abstract}

Keywords: Classification, Naive Bayes, Maize, Bangkalan, Pests and diseases 


\section{PENDAHULUAN}

Budidaya tanaman jagung merupakan hal terpenting ke 2 dalam bidang pertanian sebagai tanaman pokok setelah beras. Budidaya Jagung harus memperhatikan 8 tahapan penting yaitu memperhatikan syarat tumbuh sebelum penanaman, memilih benih, waktu penanaman, mengolah lahan, proses penanaman, pemberian pupuk, proses panen dan pasca panen. Kedelapan faktor tersebut memegang peranan penting agar produktivitasnya senantiasa dalam kondisi baik dan terus meningkat [1] [2].

Saat ini jagung tidak hanya digunakan hanya terbatas sebagai pangan. Hal lain seperti jagung sebagai pakan ternak, bahan bakar ramah lingkungan dan bahan dasar untuk kecantikan juga menggunakan jagung. Tentunya hal ini membutuhkan peningkatan produksi jagung, terutama jagung dengan kualitas terbaik.

Namun terdapat kondisi eksternal yang harus diwaspadai saat melalukan budidaya jagung. Diantaranya yaitu serangan hama dan penyakit. Ragam penelitian telah dilakukan untuk menghasilkan varietas jagung yang unggul dan tahan terhadap serangan hama dan penyakit. Namun penelitian yang telah dihasilkan hanya sampai pada pengurangan resiko penyakit yang ditimbulkan. Oleh karena itu edukasi perlu dilakukan diawal untuk pengenalan jenis-jenis penyakit yang umum menyerang tanaman jagung agar resiko serangan hama dan penyakit dapat diminimalisir.

Pada penelitian sebelumnya telah dilakukan klasifikasi penyakit tanaman jagung mengggunakan Fuzzy Multi Criteria Decision Making dengan 9 penyakit jagung dan 27 gejala. Hasil Ujicoba menunjukkan bahwa bulai dan karat daun merupakan penyakit yang banyak dijumpai pada kasus di area ujicoba [3]. Penelitian selanjutnya menggunakan Backward Chaining dengan pengetahuan terdiri dari 26 gejala penyakit, 7 penyakit jagung dan 7 solusi [4]. Berikutnya penelitian tentang klasifikasi hama dan penyakit tanaman jagung menggunakan Neural Network dan Genetic Algorithm. Penelitian ini memiliki pengetahuan yaitu 5 penyakit jagung dan 25 gejalanya [5]. Penelitian lain yang membahas hal yang sama menggunakan metode Dempster Shafer dengan 8 penyakit dan 25 gejala [6]. Selanjutnya terdapat penelitian dengan 3 penyakit jagung dan 14 gejalanya. Sistem diolah menggunakan metode Naive Bayes dengan asil akurasi 96\% [7].

Pada artikel ini dibahas tentang klasifikasi penyebab hama dan penyakit pada tanaman jagung menggunakan Naive Bayes Classifier. Pemilihan metode ini karena sederhana dan sesuai dengan kondisi data yang didapatkan.

Pada penelitian ini menggunakan pengetahuan yaitu penyakit dan gejalanya. Terdapat 15 hama dan penyakit yang menyerangnya diantaranya yaitu lalat bibit, ulat tanah, penyakit lundi (uret), penyakit bulai, penyakit virus mozaik kerdil, penggerek batang, penyakit bercak daun, penyakit hawar/upih daun, ulat grayak, penyakit busuk batang dan tongkol, penyakit karat, penyakit gosong bengkak, belalang, penggerek tongkol dan wereng jagung. Untuk gejala diambil dari penelitian sebelumnya yang telah ada [8].

\section{METODE}

Naive bayes Classifier merupakan machine learning model yang menggunakan probabilitas sederhana berdasarkan pada teorema Bayes dengan asumsi independen yang kuat (Naive). Untuk dapat melakukan tugas klasifikasi, setiap kelas diidentifikasi dengan fiturfitur yang berbeda. Namun bisa saja di kelas-kelas tertentu dapat memiliki fiturfitur yang sama. Untuk membedakannya dilakukan dengan menghitung probabilitas munculnya fitur pada kelaskelas tersebut. Naive Bayes termasuk dalam metode klasifikasi supervised learning. Keuntungan dari Naive Bayes dapat dilatih dengan data training kecil, variabel bebas dapat diasumsikan, sedangkan varian dan variabel tiap kelas 
didefinisikan. Berikut ini merupakan proses perhitungan Naive Bayes:

$$
P(A \mid B)=\frac{P(B \mid A) P(A)}{P(B)}
$$

Dengan teorema Bayes, didapatkan probabilitas A terjadi. B merupakan bukti (evidence), sedangkan A merupakan hipotesis. Asumsi yang terjadi yaitu fitur independen. Satu fitur tertentu tidak mempengaruhi yang lain, oleh karena itu disebut Naive.

Kami melakukan klasifikasi hama dan penyakit dari fitur-fitur gejala. Baris menunjukkan penyakit, sedangkan kolom diisi dengan gejala. Hal ini ditunjukkan pada Tabel 1 .

Tabel 1. Penyakit dan Gejala dari Tanaman

\begin{tabular}{|c|c|c|c|c|c|}
\hline & G1 & $\mathrm{G} 2$ & . & G45 & G46 \\
\hline P1 & $\sqrt{ }$ & $\sqrt{ }$ & & & \\
\hline P2 & & $\sqrt{ }$ & & $\sqrt{ }$ & \\
\hline . & & & & & \\
\hline P14 & & & $\sqrt{ }$ & $\sqrt{ }$ & \\
\hline P15 & & $\sqrt{ }$ & & & $\sqrt{ }$ \\
\hline
\end{tabular}

Selanjutnya teorema Bayes dapat ditulis pada persamaan berikut:

$$
P(y \mid X)=\frac{P(X \mid y) P(y)}{P(X)}
$$

Variabel $y$ merupakan kelas penyakit sebanyak 15 . Sedangkan variabel $X$ merupakan parameter atau fitur, pada kasus ini merupakan gejala.

$$
X=\left(x_{1}, x_{2}, x_{3}, \ldots x_{n}\right)
$$

$x_{1}, x_{2}, x_{3}, \ldots x_{n}$ merepresentasikan fitur gejala sebanyak 46. Dengan melakukan substitusi dan memperluas chain rule, didapatkan persamaan berikut ini:

$$
\begin{aligned}
& P\left(y \mid x_{1}, x_{2}, x_{3}, \ldots x_{n}\right)= \\
& \frac{P\left(x_{1} \mid y\right) P\left(x_{2} \mid y\right) P\left(x_{3} \mid y\right) \ldots P\left(x_{n} \mid y\right) P(y)}{P\left(x_{1}\right) P\left(x_{2}\right) \ldots P\left(x_{n}\right)}
\end{aligned}
$$

Probabilitas untuk tiap kelas dapat dihitung. Nilai penyebut statis untuk setiap kelas penyakit. Pada kasus di artikel ini variabel kelas $(y)$ berjumlah 15 . Klasifikasi bersifat multivariate, mencari nilai probabilitas y yang paling maksimum. Berikut ini persamaan yang dapat digunakan untuk menentukan kelas dengan probabilitas tertinggi dari fitur atau gejala yang diberikan [5].

$$
y=\operatorname{argmax}_{y}\left((y) \Pi_{i=1}^{n} P\left(x_{i}, y\right)\right.
$$

\section{HASIL DAN PEMBAHASAN}

Ujicoba dilakukan dengan simulasi terhadap gejala-gejala yang di-inputkan pada sistem. Penyakit dan gejala menggunakan data penelitian yang sama dengan penelitian sebelumnya. Penyakit/hama sebanyak 15 jenis sedangkan gejala sebanyak 46 [8]. Ujicoba dilakukan sebanyak 15 kali. Selanjutnya sistem akan melakukan klasifikasi untuk menentukan nilai probabilitas dari setiap kelas. Kelas dengan nilai yang paling besar menjadi pemenang. Sistem mendeteksi penyakit tertentu dari kelas pemenang. Pada Tabel

\begin{tabular}{|c|c|c|}
\hline No & Penyakit/ Hama & Gejala \\
\hline 1 & Bulai & $\begin{array}{lr}\mathrm{g} 7, \quad \mathrm{~g} 8, & \mathrm{~g} 9, \\
\mathrm{~g} 10, & \mathrm{~g} 29\end{array}$ \\
\hline 2 & Bercak daun & $\begin{array}{l}\mathrm{g} 15, \mathrm{~g} 16, \mathrm{~g} 35, \\
\mathrm{~g} 36, \mathrm{~g} 6\end{array}$ \\
\hline 3 & Hawar & $\begin{array}{l}\mathrm{g} 17, \mathrm{~g} 18, \mathrm{~g} 9, \\
\mathrm{~g} 37\end{array}$ \\
\hline 4 & Karat & $\mathrm{g} 24, \mathrm{~g} 16, \mathrm{~g} 43$ \\
\hline 5 & Lalat bibit & $\begin{array}{l}\mathrm{g} 1, \mathrm{~g} 2, \mathrm{~g} 21, \\
\mathrm{~g} 27\end{array}$ \\
\hline 6 & Ulat tanah & $\mathrm{g} 3, \mathrm{~g} 4, \mathrm{~g} 28$ \\
\hline 7 & Lundi & g5, g6 \\
\hline 8 & Virus Mozaik & $\mathrm{g} 8, \mathrm{~g} 11, \mathrm{~g} 30$ \\
\hline 9 & $\begin{array}{l}\text { Penggerek } \\
\text { batang }\end{array}$ & $\begin{array}{l}\mathrm{g} 12, \mathrm{~g} 13, \mathrm{~g} 14, \\
\mathrm{~g} 8, \mathrm{~g} 6, \mathrm{~g} 31, \\
\mathrm{~g} 32, \mathrm{~g} 33, \mathrm{~g} 34\end{array}$ \\
\hline
\end{tabular}
2 ditujukkan penyakit dan gejalagejalanya. Sedangkan pada Tabel 3 ditunjukkan gejala-gejala penyakit pada tanaman jagung.

Tabel 2. Penyakit/hama dan gejalanya 


\begin{tabular}{lll}
\hline 10 & Ulat grayak & $\mathrm{g} 8, \mathrm{~g} 20, \mathrm{~g} 38$, \\
& & $\mathrm{g} 39$ \\
11 & Belalang & $\mathrm{g} 1, \mathrm{~g} 4, \mathrm{~g} 20$ \\
12 & Wereng & $\mathrm{g} 2, \mathrm{~g} 6, \mathrm{~g} 8$, \\
$\mathrm{g} 12, \mathrm{~g} 14$ \\
13 & $\begin{array}{l}\text { Penyakit } \\
\text { gosong/bengkak }\end{array}$ & $\mathrm{g} 24, \mathrm{~g} 25, \mathrm{~g} 44$, \\
14 & $\begin{array}{l}\text { Penyakit busuk } \\
\text { batang d21, g22, g23, } \\
\text { tongkol g40 }\end{array}$ \\
15 & $\begin{array}{l}\text { Penggerek } \\
\text { tongkol }\end{array}$ & $\mathrm{g} 23, \mathrm{~g} 26, \mathrm{~g} 46$ \\
\hline
\end{tabular}

Tanaman jagung sesuai dengan data yang diambil dari Dinas pertanian Kabupaten Bangkalan memiliki 46 gejala sebagaimana disampaikan pada tabel 3 . Tabel 3. Gejala-gejala penyakit jagung

\begin{tabular}{ll}
\hline Kode & \multicolumn{1}{c}{ Gejala } \\
\hline g1 & Terdapat gigitan di daun \\
g2 & Layu pada pucuk daun \\
g3 & Terdapat batang patah di bawah \\
g4 & Terdapat gigitan pada batang \\
g5 & Rusaknya akar karena lundi \\
g6 & Jagung layu \\
g7 & Klorosis daun \\
g8 & Jagung kerdil \\
g9 & Buah tidak ada \\
g10 & Tongkol abnormal \\
g11 & Warna daun hijau kuning \\
& Terdapat bercak dan garis daun \\
g12 & kuning \\
g13 & Terdapat garis pendek putus-putus \\
& Terdapat gaun \\
g14 & daun \\
& Daun memiliki bercak cokelat \\
g15 & kelabu \\
g16 & Daun coklat \\
g17 & Bercak lebar di daun \\
g18 & Warna pelepah merah keabuan \\
g19 & Terdapat butiran warna putih \\
g20 & Rusaknya tulang daun \\
g21 & Busuk batang \\
g22 & taya kering pada bagian atas \\
g23 & Tongkol rusak \\
g24 & Terdapat titik merah coklat karat \\
g25 & Pembungkus rusak pada tongkol \\
\hline &
\end{tabular}

\begin{tabular}{ll}
\hline g26 & Ulat di tongkol \\
g27 & Daun kekuningan \\
g28 & Daun pada tanaman muda rusak \\
& Terdapat lapisan beledu putih pada \\
g29 & daun di pagi hari \\
g30 & Pada daun terdapat serbuk spora \\
g31 & Terdapat lubang kecil di daun \\
g32 & Lubang seperti gorokan di batang \\
g33 & Batang dan tassel mudah patah \\
g34 & Tumpukan tassel yang rusak \\
g35 & Biji rusak, busuk, tongkol rusak \\
& Biji terdapat miselium abu-abu \\
g36 & hingga hitam \\
g37 & Tanaman cepat kering dan mati \\
g38 & Daun seperti transparan \\
g39 & lubang bahkan tinggal tulang \\
& Batang dan tongkol merah jambu, \\
g40 & kecoklatan \\
g41 & Tanaman mudah rontok, rebah \\
g42 & Batang kulit tipis \\
g43 & Memiliki serbuk kuning coklat \\
g44 & Biji jagung bengkak hitam \\
g45 & Biji jagung bengkak keluar \\
g46 & Memiliki kotoran pada tongkol \\
\hline &
\end{tabular}

Selanjutnya disimulasikan ujicoba menggunakan citra penyakit pada tanaman jagung yang didapatkan secara publik di Internet. Data ujicoba ditunjukkan pada Gambar 1.

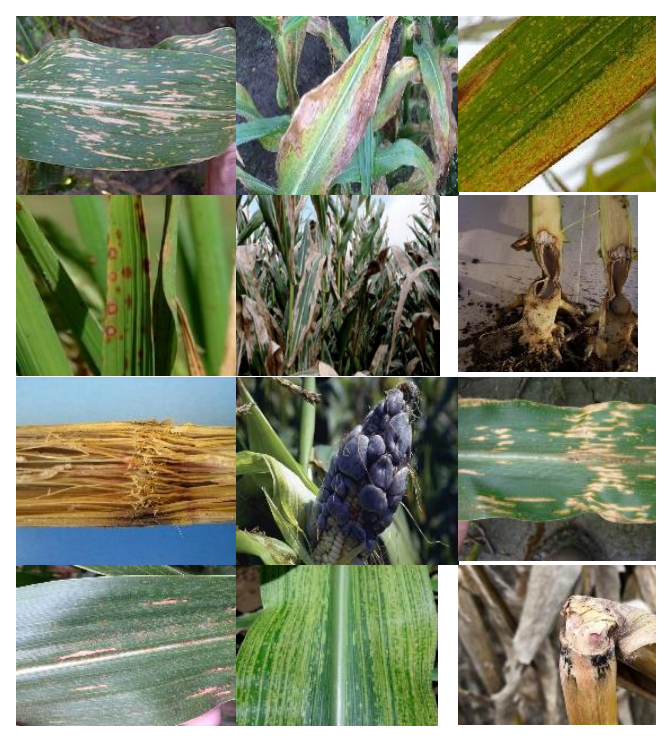




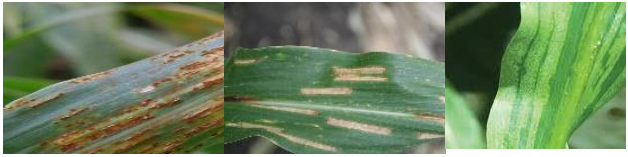

Gambar 1. Citra penyakit jagung

Dari Gambar 1, dilakukan identifikasi gejala-gejala yang terdapat pada data uji coba. Pada Tabel 4 ditunjukkan gejala-gejala yang terdapat 15 data ujicoba.

Tabel 4. Gejala-gejala yang teridentifikasi dari data uji coba

\begin{tabular}{ll}
\hline No & Gejala \\
\hline 1 & g7, g15, g16, g17 \\
2 & g2, g6, g7, g15, g16, g17 \\
3 & g15, g17, g24, g27, g31 \\
4 & g15, g16, g17, g22, g24, g28 \\
5 & g11, g12, g13, g14 \\
6 & g5, g6, g8, g9, g32, g33 \\
7 & g4, g21, g22, g32, g42 \\
8 & g10, g23, g25, g44, g46 \\
9 & g13, g15, g22 \\
10 & g15, g16, g17 \\
11 & g11, g12, g13, g14, g27 \\
12 & g15, g16, g17, g20 \\
13 & g2, g15, g16, g17, g20, g22 \\
14 & g15, g16, g17, g24 \\
15 & g3, g6, g21, g33, g37 \\
\hline
\end{tabular}

Setelah data ujicoba dan gejala didapatkan. Selanjutnya melakukan klasifikasi penyakit/hama pada data ujicoba. Tahapan sistem klasifikasi penyakit/hama menggunakan Naive Bayes classifier dapat dijelaskan sebagai berikut :

1. Pilih satu data ujicoba dan lakukan pengamatan. Misalnya menggunakan data 01 pada Gambar 2.

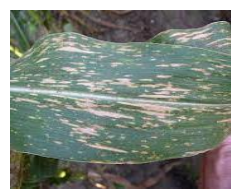

Gambar 2. Data ujicoba 01

2. Menentukan nilai $n$ (penyakit $=1$ ), $p$ (probabilitas penyakit $1 / 15=$ $0,6667) m$ (jumlah gejala keseluruhan = 46), $n_{c}$ (bersifat biner, nilai $n_{c}=1$ jika ada gejala, nilai $n_{c}=0$ jika tidak ada gejala). Setiap penyakit/ hama dihitung nilai $n, p, m$ dan $n_{c}$.
Sebagaimana disampaikan ada Tabel 4. Data ke 1 memiliki gejala ke 7, 15, 16 dan 17. Gejala tersebut yaitu klorosis daun, daun memiliki bercak cokelat kelabu, daun coklat, bercak lebar di daun. Jadi nilai $n_{7}, n_{15}, n_{16}, n_{17}=1$. Selain itu nilai $n_{c}$ lain $=0$

3. Hitung $P\left(\mathrm{ai}_{\mathrm{i}} \mid \mathrm{V}_{\mathrm{j}}\right)$ yaitu probabilitas setiap penyakit jagung. Hitung perobabilitas penyakit dari penyakit 1 bulai hingga penyakit 15 penggerek tongkol.

Penyakit jagung 1 . Bulai

$$
\begin{aligned}
P(7 \mid B) & =\frac{1+46 \times 0,6667}{1+46} \\
& =\frac{31,6682}{47} \\
& =0,673791 \\
P(8,9,10,29 \mid B)=\frac{0+46 \times 0,6667}{1+46} & \\
= & \frac{30,6682}{47} \\
& =0,652515
\end{aligned}
$$

Penyakit ke 2 hingga penyakit ke 15 hitung sebagaimana penyakit 1 .

4. Kalkulasi nilai $P\left(\mathrm{a}_{\mathrm{i}} \mid \mathrm{v}_{\mathrm{j}}\right)$ tiap gejala pada penyakit dengan $p(0,6667)$

Penyakit 1 . Bulai

$$
\begin{gathered}
P\left(\mathrm{ai}_{i} \mid \mathrm{V}_{\mathrm{i}}\right) \times p=0,673791 \times 0,652515 \times \\
0,652515 \times 0,652515 \times 0,652515 \\
=0,122148
\end{gathered}
$$

Hitung kalkulasi dari $P\left(\mathrm{a}_{\mathrm{i}} \mid \mathrm{V}_{\mathrm{i}}\right)$ dan $p$ $(0,6667)$ untuk penyakit ke 2 hingga penyakit ke 15.

5. Descending hasil kalkulasi pada langkah 4 dari 15 penyakit/hama jagung. Nilai terbesar menjadi pemenang. Data Ujicoba terdiagnosa penyakit tertentu.

6. Lakukan seterusnya hingga data ujicoba terakhir (data ke 15).

Hasil klasifikasi dari sistem selanjutnya dilakukan validasi oleh pakar, tabel 5 menunjukkan hal tersebut. 
Tabel 5. Validasi penyakit jagung oleh pakar

\begin{tabular}{cll}
\hline No & \multicolumn{1}{c}{$\begin{array}{c}\text { Hasil dari } \\
\text { sistem }\end{array}$} & Validasi pakar \\
\hline 1 & Bercak daun & Bercak daun \\
2 & Hawar & Hawar \\
3 & Bercak daun & Bercak daun \\
4 & Karat & Karat \\
5 & Penggerek & Bulai \\
& batang & \\
6 & Penggerek & Penggerek \\
& batang & batang \\
7 & Penyakit busuk & Penyakit \\
& batang dan & busuk batang \\
& tongkol & dan tongkol \\
8 & Penggerek & Penggerek \\
& tongkol & tongkol \\
9 & Bercak & Karat \\
& daun/penggerek & \\
& batang & \\
10 & Bercak daun & Bercak daun \\
11 & Penggerek & Bulai \\
& batang & \\
12 & Bercak daun & Bercak daun \\
13 & Bulai & Bulai \\
14 & Bercak daun & Bercak daun \\
15 & Bercak daun/ & Busuk Batang \\
& hawar/penyakit & \& tongkol \\
& busuk batang \& & \\
& tongkol & \\
\hline & Pakar berasa dan \\
\end{tabular}

Pakar berasal dari Dinas pertanian kabupaten bangkalan. Dari hasil ujicoba pada Tabel 5 menunjukkan bahwa 11 dari 15 ujicoba kasus teridentifikasi benar sesuai dengan pendapat pakar. Untuk itu akurasi yang diperoleh dari sistem didapatkan:

$$
\text { Akurasi }=\frac{11}{15} \times 100 \%=73,33 \%
$$

Untuk mendukung kemudahan antarmuka dengan user maka dibuat desain awal sistem. Pada Gambar 3, 4 dan 5 menunjukkan desain antarmuka sistem klasifikasi jagung.

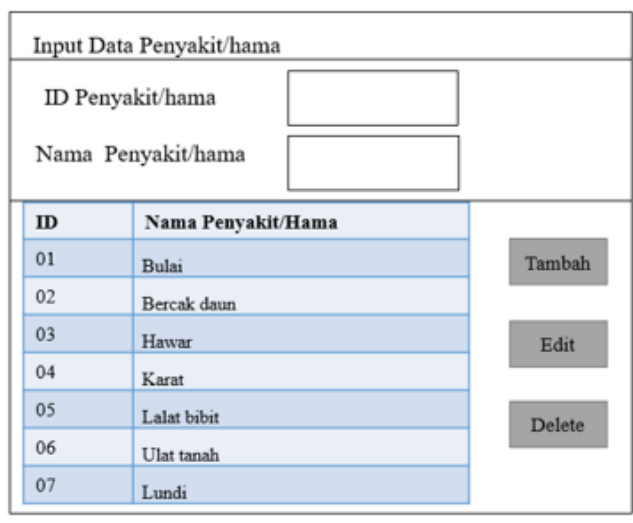

Gambar 3. Input/Edit/Delete Data Penyakit/Hama Jagung

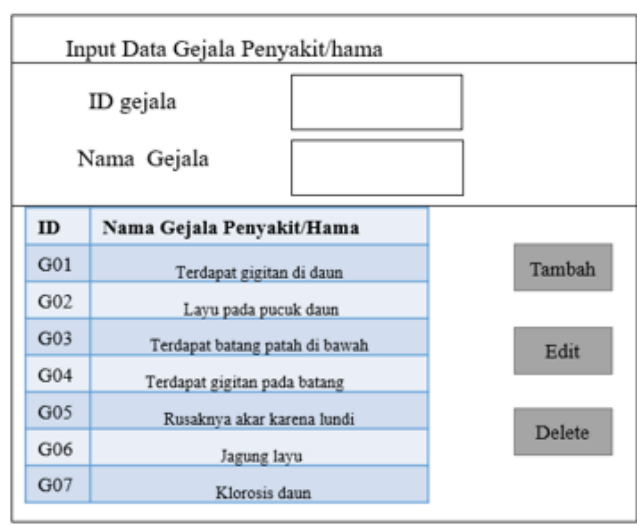

Gambar 4. Input/Edit/Delete Data gejala Penyakit/Hama Jagung

Desain antarmuka pada Gambar 3 dan 4 melakukan operasi input, edit dan delete untuk nama penyakit dan gejala penyakit pada tanaman jagung. Sistem yang dibuat dapat berjalan secara dinamis menyesuaikan kebutuhan dari database di tiap daerah yang dilakukan identifikasi penyakit dan hama tanaman jagung. 


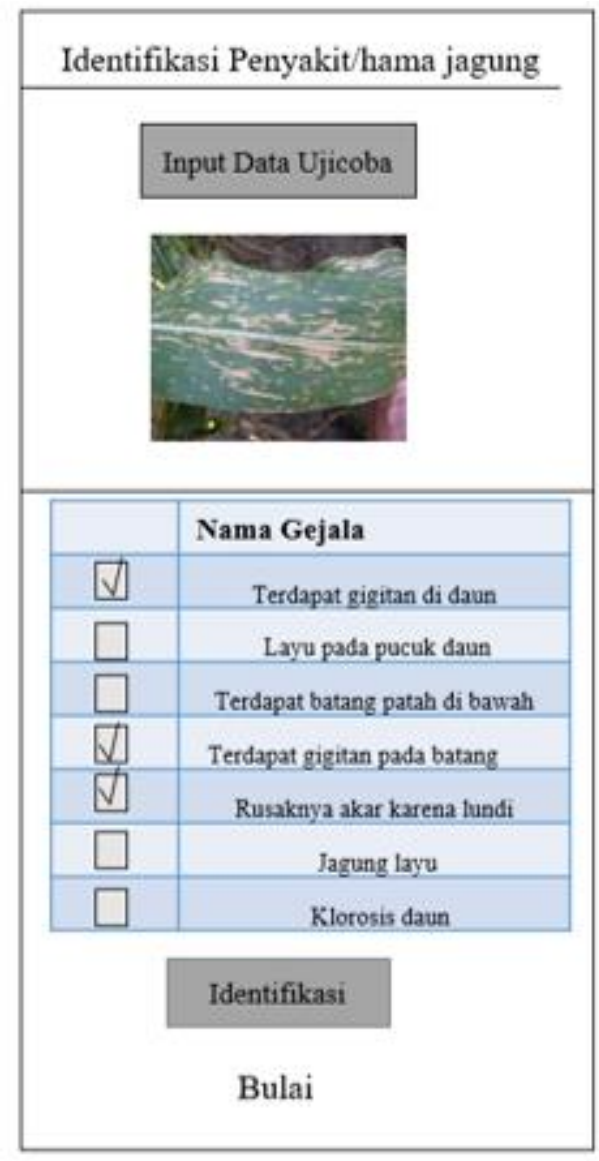

Gambar 5. Hasil Klasifikasi Penyakit/Hama Jagung

Antarmuka akan memudahkan user untuk memahami proses input penyakit, gejala dan identifikasi hasil klasifikasi.

\section{SIMPULAN}

Pada artikel ini telah dibahas tentang klasifikasi hama dan penyakit pada tanaman jagung menggunakan Naive Bayes Classifier. Ujicoba dilakukan dengan simulasi melalui 15 citra tanaman jagung. Identifikasi dilakukan untuk mendapatkan gejala-gejala yang menyerang. Hasil ujicoba menunjukkan akurasi hingga $73,33 \%$.

\section{SARAN}

Algoritma Naive Bayes merupakan algoritma yang sederhana dan mudah diimplementasikan. Kekurangannya yaitu pada fitur tidak semuanya independen, sehingga dapat mempengaruhi performansi dari hasil klasifikasi.

Untuk penelitian selanjutnya dapat melibatkan pakar lebih intensif dengan melakukan pembobotan pada setiap gejala yang menyertai penyakit. Selanjutnya data dapat diolah menggunakan metode klasifikasi lain seperti Certainty Factor, Dempster-Shafer dan Decision Tree. Hasil akurasi dapat dibandingkan dengan penelitian yang telah ada, tentunya dengan menggunakan data yang sama agar proses perbandingan dapat dilakukan dengan seimbang.

\section{UCAPAN TERIMA KASIH}

Penelitian ini merupakan hasil program MBKM kampus merdeka yang melibatkan mahasiswa dan merupakan salah satu output penelitian mandiri kolaborasi nasional dengan dukungan dana DIPA Universitas Trunojoyo Madura No 3128/UN46.4.1/ PT.01.03/2021.

\section{DAFTAR PUSTAKA}

[1] B. P. T. P. N. Badan Ketahanan Pangan Dan Penyuluh Pertanian Aceh, "Budidaya Tanaman Jagung," Badan Penelitian dan Pengembangan Pertanian, pp. 121, 2009.

[2] T. Mutiarawati, F. Pertanian, and U. Padjadjaran, "Penanganan Pasca Panen Hasil Pertanian," 2007.

[3] E. Munanda and N. Prihatin, "Tanaman Jagung Menggunakan Fuzzy Mcdm Berbasis Web," $J$. Litek, vol. 10, no. 2, pp. 113-117, 2010.

[4] S. Wulandari, "Aplikasi Sistem pakar mendiagnosa Penyakit pada Tanaman Jagung menggunakan metode Backward Chaining," 2019.

[5] Rais, "Klasifikasi hama dan penyakit Tanaman Jagung dengan menggunakan Neural Network berbasis Algoritma Genetika," in SENIT, 2016, vol. 1, pp. 51-56.

[6] K. M. Khoirunnisak, "Sistem Pakar Diagnosa Penyakit Pada Tanaman Jagung Dengan Metode Dempster Shafer," 2005.

[7] A. Syarifudin et al., "Sistem Pakar Diagnosis Penyakit Pada Tanaman 
Jurnal SimanteC Vol. 10, No. 1 Desember 2021

Jagung Menggunakan Metode Naive Bayes Berbasis Android," Semesta Tek., vol. 21, no. 2, pp. 1492-1500, 2018.

[8] M. Syarief, A. Mukminin, N. Prastiti, and W. Setiawan, "Penerapan Metode Naive Bayes Classifier Untuk Deteksi Penyakit pada Tanaman Jagung," Nero, vol. 3, no. 1, pp. 61-68, 2017. 